\title{
NR4A3 (NOR-1) Immunostaining Shows Better Performance than DOG1 Immunostaining in Acinic Cell Carcinoma of Salivary Gland: a Preliminary Study
}

\author{
Adepitan Owosho ${ }^{1}$, Donald Tyler ${ }^{2}$, Olufunlola Adesina ${ }^{3}$, Oluwole Odujoko ${ }^{4}$, Kurt Summersgill ${ }^{5}$ \\ ${ }^{1}$ Missouri School of Dentistry, A.T. Still University, Kirksville, Missouri, United States. \\ ${ }^{2}$ Joint Base San Antonio-Lackland Air Force Base, San Antonio, Texas, United States. \\ ${ }^{3}$ Department of Oral and Maxillofacial Surgery and Oral Pathology, Faculty of Dentistry, Obafemi Awolowo University, \\ Ile-Ife, Nigeria. \\ ${ }^{4}$ Department of Morbid Anatomy and Forensic Medicine, Obafemi Awolowo University Teaching Hospital, Ile-Ife, Nigeria. \\ ${ }^{4}$ Department of Diagnostic Sciences, School of Dental Medicine, University of Pittsburgh, Pittsburgh, Pennsylvania, \\ United States.
}

\author{
Corresponding Author: \\ Adepitan Owosho \\ Missouri School of Dentistry and Oral Health \\ A. T. Still University \\ 800 W Jefferson Street, Kirksville, Missouri 63501 \\ United States \\ Phone: +1 6606262843 \\ E-mail: adepitanowosho@atsu.edu
}

\begin{abstract}
Objectives: Acinic cell carcinoma of salivary gland harbours recurrent and specific chromosomal rearrangement $[\mathrm{t}(4 ; 9)$ (q13;q31)], resulting in the translocation of secretory calcium-binding phosphoprotein gene cluster at $4 \mathrm{q} 13$ to nuclear receptor subfamily 4 group a member 3 at $9 \mathrm{q} 31$. This upregulates the transcription factor nuclear receptor subfamily 4 group A member 3 , which can be detected by immunohistochemistry. The purpose of this pilot study is to evaluate the performance of nuclear receptor subfamily 4 group A member 3 immunostaining on whole-slide acinic cell carcinoma tissue, in comparison with discovered on GIST-1 immunostaining.

Material and Methods: We retrieved 6 cases of acinic cell carcinoma (AciCC), including 5 conventional low-grade and 1 dedifferentiated high-grade. Immunohistochemistry (IHC) for nuclear receptor subfamily 4 group A member 3 (NR4A3) and discovered on GIST-1 (DOG1) were performed at the University of Pittsburgh Medical Centre in Pittsburgh, Pennsylvania on all retrieved cases.

Results: The result shows that NR4A3 IHC shows better performance than DOG1 IHC: 5 of the $6(83.3 \%)$ AciCC cases (including the dedifferentiated high-grade) demonstrated strong diffuse nuclear staining for NR4A3, also five AciCC cases (including the dedifferentiated high-grade) demonstrated weak to moderate membranous staining with variable distribution for DOG1. Moreover, only $3(50 \%)$ cases showed complete membranous staining with DOG1.

Conclusions: This pilot study showed that nuclear receptor subfamily 4 group A member 3 immunostaining is a sensitive marker for acinic cell carcinoma and of better utility than discovered on GIST-1 immunostaining in making a diagnosis of acinic cell carcinoma.
\end{abstract}

Keywords: gene rearrangement; immunohistocytochemistry; malignant neoplasms.

Accepted for publication: 24 February 2021

To cite this article:

Owosho A, Tyler D, Adesina O, Odujoko O, Summersgill K.

NR4A3 (NOR-1) Immunostaining Shows Better Performance than DOG1 Immunostaining in Acinic Cell Carcinoma of Salivary Gland: a Preliminary Study

J Oral Maxillofac Res 2021;12(1):e4

URL: http://www.ejomr.org/JOMR/archives/2021/1/e4/v12n1e4.pdf

doi: $10.5037 /$ jomr.2021.12104 


\section{INTRODUCTION}

Acinic cell carcinoma (AciCC) of salivary gland is a rare tumour accounting for approximately $10 \%$ of primary salivary gland malignancies [1]. It is most commonly located in the parotid gland and occurs more commonly in females [2]. AciCC originates from the acinar epithelium, showing serous differentiation resembling normal acini of salivary glands. AciCC usually presents as a lowgrade malignancy with favourable prognosis; a small proportion of them could be associated with dedifferentiated high-grade transformation with poorer prognosis $[\underline{3}, \underline{4}]$.

Until recently, the diagnosis of AciCC was solely based on its acinar differentiation aided by demonstrating cytoplasmic PAS-positive zymogen granules and non-specific membranous/cytoplasmic immunohistochemical expression of discovered on GIST-1 (DOG1), a marker of acinar and intercalated duct differentiation $[\underline{3}, \underline{5}, \underline{6}]$. In 2019, whole-genome sequencing of AciCC of salivary gland identified a recurrent and specific $[\mathrm{t}(4 ; 9)(\mathrm{q} 13 ; \mathrm{q} 31)]$ genomic rearrangement [7]. This rearrangement results in the translocation of the active enhancer regions from the secretory calcium-binding phosphoprotein (SCPP) gene cluster at $4 \mathrm{q} 13$ to the transcription start site of transcription factor nuclear receptor subfamily 4 group A member 3 (NR4A3) at 9q31, leading to the up-regulation of NR4A3 []]. The overexpression of the NR4A3 protein can be detected by immunohistochemistry (IHC) and has been shown to be more sensitive for AciCC than NR4A3 FISH by being present in AciCC that are negative for SCPPNR4A3 translocation [] $]$. A minor subset $(<5 \%)$ of AciCC harbours the HTN3-MSANTD3 translocation $[\underline{9}, \underline{10}]$. Interestingly, this subset of AciCC expresses NR4A3 by IHC $[\underline{8}, 11]$. NR4A3 expression has not been reported in any other salivary gland neoplasm $[\underline{8}, \underline{11}, \underline{12}]$.

The aim of this observatory pilot study is to evaluate the performance of nuclear receptor subfamily 4 group A member 3 immunostaining on whole-slide (conventional low-grade and dedifferentiated highgrade) acinic cell carcinoma tissue and in comparison to discovered on GIST-1 immunostaining.

\section{MATERIAL AND METHODS}

The study was approved by the Ethics and Research Committee of Obafemi Awolowo University Teaching Hospitals Complex, Obafemi Awolowo University,
Ile-Ife, Nigeria (Protocol No: ERC/2019/06/06) and exempt from review by the Institutional Review Board of A.T. Still University, Kirksville, United States, for not being a human subject study. Cases of acinic cell carcinomas were retrieved from Joint Base San Antonio-Lackland Air Force Base (Brooke Army Medical Centre and Wilford Hall Ambulatory Surgical Centre), Texas and Department of Morbid Anatomy and Forensic Medicine, Obafemi Awolowo University Teaching Hospital, Ile-Ife, Nigeria August 2020 to September 2020. IHC for NR4A3 and DOG1 were performed at the University of Pittsburgh Medical Centre in Pittsburgh, Pennsylvania on all retrieved cases from August 2020 to September 2020. IHC for DOG1 (1 : 50 dilution; RM-9132-5 [1.1] Thermo Fisher Scientific; Waltham, Massachusetts, United States) was performed using an automated IHC system (Ventana BenchMark ${ }^{\circledR}$ ULTRA - Roche Diagnostics; Basel, Switzerland) on $4-\mu \mathrm{m}$-thick sections of formalin-fixed paraffin-embedded (FFPE) tissue. DOG1 staining was classified based on its distribution as membranous (apical or complete) and/or cytoplasmic. IHC for NR4A3 (NOR-1) (1 : 50 dilution; SC-393902 [H-7] - Santa Cruz Biotechnology, Inc.; Dallas, Texas, United States) was performed using an automated IHC system (Leica Bond-III - Leica Biosystems; Wetzlar, Germany) on $4-\mu$ m-thick sections of FFPE tissue. Only nuclear staining was considered positive in the interpretation of NR4A3 IHC. Distribution of staining was scored as: 0 (no staining), $1+(1$ to $33 \%$ ), $2+$ (34 to $66 \%$ ), and $3+(67$ to $100 \%)$ and intensity (weak, moderate or strong) for both NR4A3 and DOG1. Staining of any intensity in at least $1 \%$ of neoplastic cells was considered positive, as previously described [11].

\section{RESULTS \\ Clinicopathologic characteristics of cohort}

A total of 6 AciCC of salivary gland cases were retrieved. Patient demographics are presented in Table 1. All patients were females with ages ranging

Table 1. Clinicopathologic features of acinic cell carcinomas

\begin{tabular}{c|c|c|c|c|c}
\hline $\begin{array}{c}\text { Case } \\
\text { no. }\end{array}$ & $\begin{array}{c}\text { Age } \\
\text { (years) }\end{array}$ & Gender & Location & $\begin{array}{c}\text { Size } \\
(\mathbf{c m})\end{array}$ & Diagnosis \\
\hline Case 1 & 45 & Female & Parotid & 2.1 & Conventional \\
\hline Case 2 & 83 & Female & Parotid & 4.4 & Dedifferentiated \\
\hline Case 3 & 37 & Female & Parotid & 2 & Conventional \\
\hline Case 4 & 74 & Female & Parotid & 3 & Conventional \\
\hline Case 5 & 55 & Female & Parotid & 2 & Conventional \\
\hline Case 6 & 30 & Female & Parotid & 4 & Conventional \\
\hline
\end{tabular}


from 30 to 83 years old (median, 50 years). All tumours were located in the parotid gland. The size of the tumours ranged from 2 to $4.4 \mathrm{~cm}$. Five cases are conventional low-grade and 1 case showed dedifferentiated high-grade transformation areas.

\section{Immunohistocytochemistry}

Results of NR4A3 and DOG1 IHCs are summarized in Table 2. For NR4A3, 5 (83.3\%) AciCC cases (cases 1 to 5) demonstrated strong nuclear reactivity in $67-100 \%$ of neoplastic cells (3+) (Figures 1, 2 and 3). One case (case 6) showed no nuclear reactivity in any neoplastic cells (0). Acinar cells in normal salivary gland tissue in all cases showed no reactivity to NR4A3. For DOG1, 5 (83.3\%) AciCC cases (cases 1 - 4, 6) demonstrated any reactivity in neoplastic cells (at least weak intensity of at least $1+$ distribution) (Figures 1 and 2).

Table 2. Summary of NR4A3 and DOG1 immunohistochemistry result

\begin{tabular}{|c|c|c|c|c|c|c|c|c|}
\hline \multirow{3}{*}{$\begin{array}{c}\text { Case } \\
\text { no. }\end{array}$} & \multicolumn{3}{|c|}{ NR4A3 IHC } & \multicolumn{5}{|c|}{ DOG1 IHC } \\
\hline & \multirow{2}{*}{ Interpretation } & \multirow{2}{*}{ Intensity } & \multirow{2}{*}{ Distribution } & \multirow{2}{*}{$\begin{array}{c}\text { Any } \\
\text { staining }\end{array}$} & \multirow{2}{*}{$\begin{array}{c}\text { Apical } \\
\text { membranous } \\
\text { staining } \\
\end{array}$} & \multicolumn{3}{|c|}{ Complete membranous staining } \\
\hline & & & & & & Interpretation & Intensity & Distribution \\
\hline Case 1 & Positive & Strong & $3+$ & Positive & - & Positive & Weak-moderate & $3+$ \\
\hline Case 2 & Positive & Strong & $3+$ & Positive & - & Positive & Weak-moderate & $3+$ \\
\hline Case 3 & Positive & Strong & $3+$ & Positive & Yes & Negative & NA & NA \\
\hline Case 4 & Positive & Strong & $3+$ & Positive & - & Positive & Weak-moderate & $3+$ \\
\hline Case 5 & Positive & Strong & $3+$ & Negative & - & Negative & NA & NA \\
\hline Case 6 & Negative & NA & 0 & Positive & Yes & Negative & NA & NA \\
\hline
\end{tabular}

$\mathrm{NA}=$ not applicable, $\mathrm{IHC}=$ immunohistochemistry.
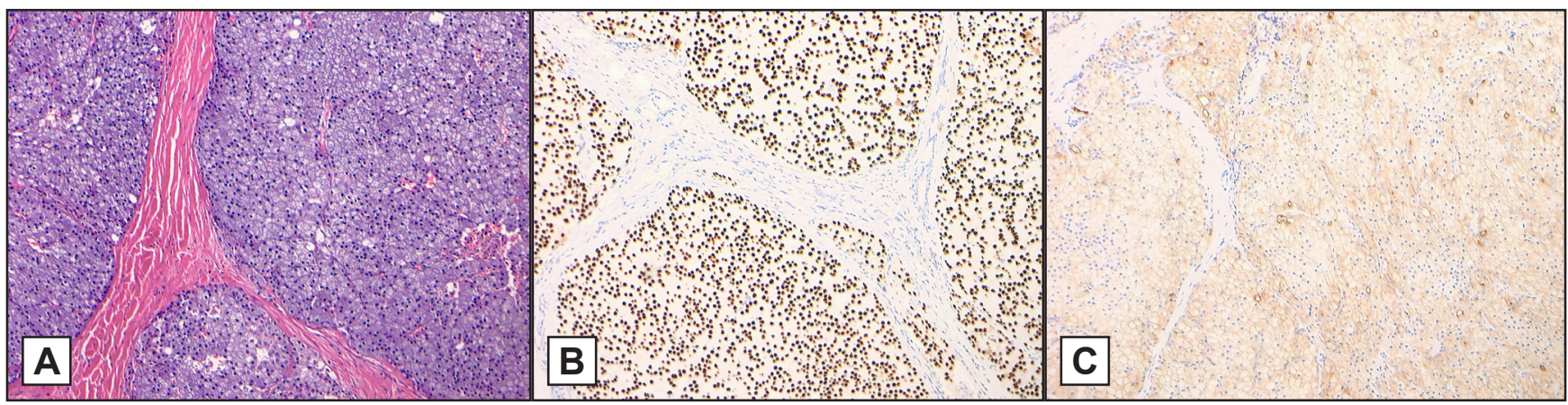

Figure 1. Histopathology of case 1, conventional acinic cell carcinoma of the parotid gland in a 45-year old female.

$\mathrm{A}=$ morphology shows a solid lobulated growth pattern separated by fibrous septa with prominent basophilic zymogen granules (haematoxylin and eosin, original magnification $\mathrm{x} 100$ ).

$\mathrm{B}=$ strong diffuse nuclear staining with NR4A3 IHC (original magnification $\mathrm{x} 100$ ).

$\mathrm{C}=$ weak to moderate diffuse complete membranous staining with DOG1 IHC (original magnification $\mathrm{x} 100$ ).
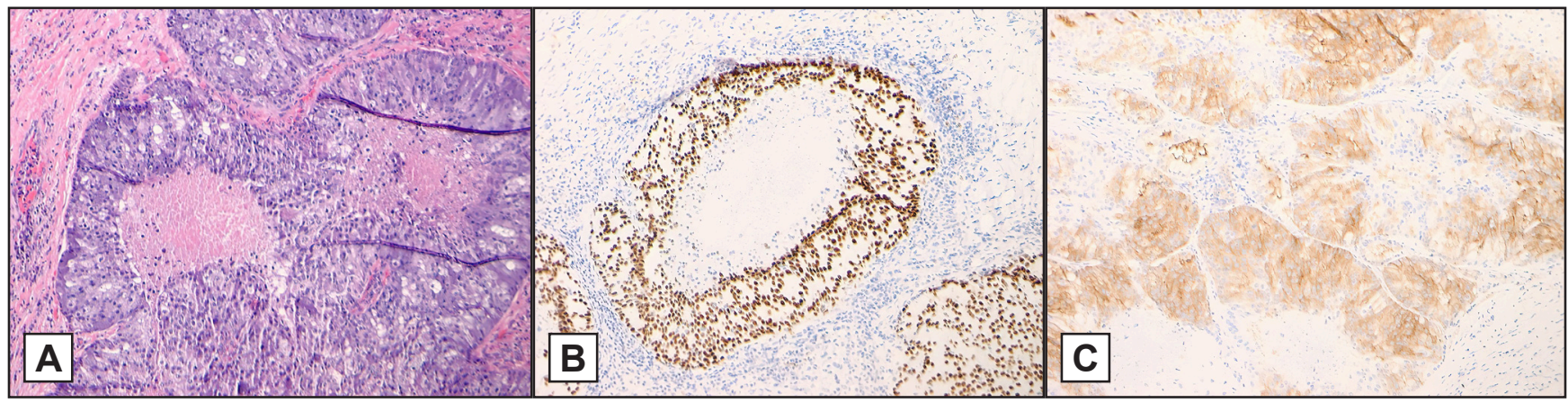

Figure 2. Histopathology of case 2, dedifferentiated high-grade acinic cell carcinoma of the parotid gland in an 83-year old female. $\mathrm{A}=$ morphology shows tumour nest with areas of central comedo necrosis (haematoxylin and eosin, original magnification $\mathrm{x} 100$ ).

$\mathrm{B}=$ strong diffuse nuclear staining with NR4A3 IHC (original magnification $\mathrm{x} 100$ ).

$\mathrm{C}=$ weak to moderate diffuse complete membranous staining with DOG1 IHC (original magnification $\mathrm{x} 100$ ). 


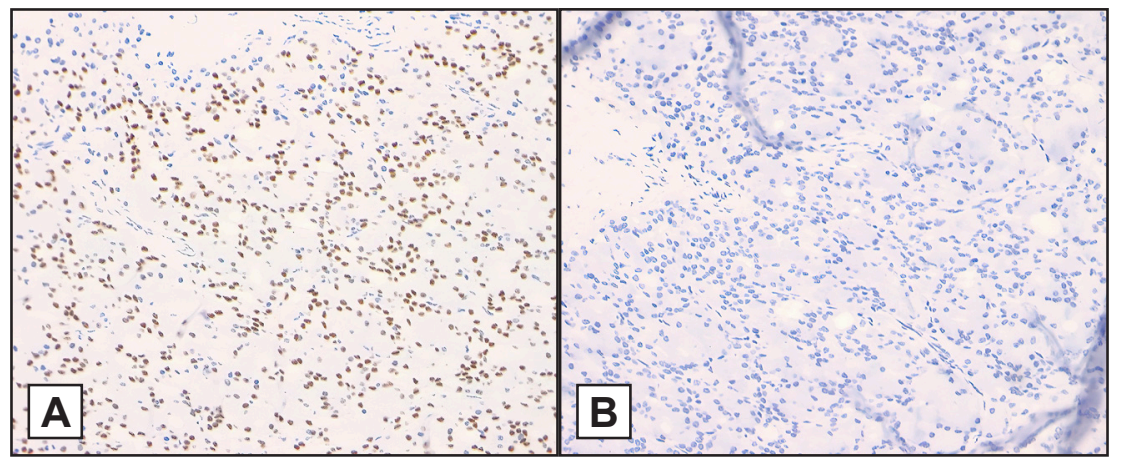

Figure 3. Histopathology of case 5, conventional acinic cell carcinoma of the parotid gland in a 55-year old female. A = strong diffuse nuclear staining with NR4A3 IHC (original magnification x200).

$\mathrm{B}=$ no staining with DOG1 IHC (original magnification $\mathrm{x} 200$ ).

Three of the 5 cases (cases 1, 2 and 4) demonstrated weak to moderate complete membranous and some cytoplasmic staining in $67-100 \%$ distribution $(3+)$ (Figures 1 and 2). Case 5 showed no reactivity (0) and cases 3 and 6 only demonstrated weak apical membranous staining $(1+)$. Acinar cells in normal salivary gland tissue in all cases showed canalicular pattern of staining to DOG1.

\section{DISCUSSION}

AciCC of salivary gland is characterized by recurrent and specific chromosomal rearrangement $[\mathrm{t}(4 ; 9)$ (q13;q31)], resulting in the translocation of SCPP gene cluster at $4 \mathrm{q} 13$ to NR4A3 at $9 \mathrm{q} 31$ [7]. This upregulates the transcription factor NR4A3, which can be detected by IHC. NR4A3 (NOR-1) IHC has been evaluated in 94 cases of AciCC and in 157 nonAciCC salivary gland tumours (including secretory carcinoma, mucoepidermoid carcinoma, adenoid cystic carcinoma, salivary duct carcinoma, basal cell adenocarcinoma, myoepithelial carcinoma, epithelialmyoepithelial carcinoma, clear cell carcinoma, carcinoma ex-pleomorphic adenoma, adenocarcinoma NOS, pleomorphic adenoma, Warthin tumour, oncocytoma, and myoepithelioma) by 4 recent studies, reporting a $97.9 \%$ sensitivity and $100 \%$ specificity as a nuclear marker for AciCC $[\underline{8}, \underline{11-13}]$. NR4A3 by FISH in AciCC is $100 \%$ specific; however, its sensitivity has been reported to be lower $(53 / 69$, $76.8 \%)[\underline{8}, 11]$. In this study, 5 out of 6 AciCC cases were positive for NR4A3 IHC.

Several salivary gland tumours are characterized by recurrent chromosomal rearrangements, such as PLAG1 rearrangements in pleomorphic adenoma [14], PRKD1 rearrangements in cribriform adenocarcinoma/polymorphous adenocarcinoma [15], EWSR1 rearrangement in hyalinising clear cell carcinoma [16], MYB/MYBL1-NFIB in adenoid cystic carcinoma [17], CRTC1/CRTC3-MAML2 in mucoepidermoid carcinoma [18], NCOA4/ TRIM27-RET in intraductal carcinoma of salivary glands [19], MEF2C-SS18 in microsecretory adenocarcinoma [20], and ETV6 rearrangements in secretory carcinoma of salivary glands [21]. Similar to NR4A3, transcription factors PLAG1 and MYB are upregulated in pleomorphic adenoma and adenoid cystic carcinoma, respectively. However, PLAG1 and MYB IHC are not specific to pleomorphic adenoma and adenoid cystic carcinoma [22,23], unlike NR4A3 IHC, which appears to be specific for AciCC in salivary tumours. NR4A3 rearrangement was initially described in extraskeletal myxoid chondrosarcoma with various gene partners such as EWSR1, FUS, TAF15, TCF12, HSPA8, and TFG. However, NR4A3 IHC lacks sensitivity for the diagnosis of extraskeletal myxoid chondrosarcoma [13] .

AciCCs that are negative for NR4A3 IHC or NR4A3 by FISH may be because of alternative genomic rearrangement involving the other two subfamilies of NR4A nuclear receptors; NR4A1 (Nur77) and NR4A2 (Nurr1) [24]. One case of AciCC in Haller et al. [24], that was negative for NR4A3 IHC was found to be positive for NR4A2 (Nurr1) IHC, suggesting that NR4A2 could be an alternative oncogenic driver in rare cases of AciCCs that lack NR4A3 rearrangement. In our study, one case was negative for NR4A3 IHC could be positive for NR4A2 IHC, but it was not tersted.

\section{CONCLUSIONS}

Despite the limitations of this pilot study a comparison of nuclear receptor subfamily 4 group A member 3 and discovered on GIST-1 immunostaining in acinic cell carcinomas demonstrated that nuclear receptor subfamily 4 group A member 3 immunostaining shows better performance than discovered on 
GIST-1 immunostaining. All positive nuclear receptor subfamily 4 group A member 3 staining acinic cell carcinomas in this study demonstrated a strong intensity, with $3+$ staining distribution, while discovered on GIST-1 staining demonstrated weak to moderate apical/complete membranous and cytoplasmic staining with variable distribution. Nonneoplastic salivary gland tissue showed no reactivity at all to nuclear receptor subfamily 4 group A member 3 immunostaining, while discovered on GIST1 staining was present in non-neoplastic salivary gland tissue. The nuclear staining of nuclear receptor subfamily 4 group A member 3 immunostaining was easier to interpret compared to the membranous staining of discovered on GIST-1 immunostaining. In conclusion, the presented study showed that nuclear receptor subfamily 4 group A member 3 immunostaining is a sensitive marker for salivary gland acinic cell carcinoma and of better utility than discovered on GIST-1 immunostaining in making a diagnosis of salivary gland acinic cell carcinoma.

\section{ACKNOWLEDGMENTS AND DISCLOSURE STATEMENTS}

The authors report no conflicts of interest related to this report.

\section{REFERENCES}

1. Bjørndal K, Krogdahl A, Therkildsen MH, Overgaard J, Johansen J, Kristensen CA, Homøe P, Sørensen CH, Andersen E, Bundgaard T, Primdahl H, Lambertsen K, Andersen LJ, Godballe C. Salivary gland carcinoma in Denmark 1990-2005: a national study of incidence, site and histology. Results of the Danish Head and Neck Cancer Group (DAHANCA). Oral Oncol. 2011 Jul;47(7):677-82. [Medline: 21612974] [doi: 10.1016/j.oraloncology.2011.04.020]

2. Yibulayin F, Feng L, Wang M, Lu MM, Luo Y, Liu H, Yang ZC, Wushou A. Head \& neck acinar cell carcinoma: a population-based study using the seer registry. BMC Cancer. 2020 Jul 8;20(1):631. [Medline: 32641007] [PMC free article: 7346396$]$ [doi: $10.1186 / \mathrm{s} 12885-020-07066-\mathrm{y}]$

3. Chiosea SI, Griffith C, Assaad A, Seethala RR. The profile of acinic cell carcinoma after recognition of mammary analog secretory carcinoma. Am J Surg Pathol. 2012 Mar;36(3):343-50. [Medline: 22301503] [doi: 10.1097/PAS.0b013e318242a5b0]

4. Thompson LD, Aslam MN, Stall JN, Udager AM, Chiosea S, McHugh JB. Clinicopathologic and Immunophenotypic Characterization of 25 Cases of Acinic Cell Carcinoma with High-Grade Transformation. Head Neck Pathol. 2016 Jun;10(2):152-60. [Medline: 26245749] [PMC free article: 4838973] [doi: 10.1007/s12105-015-0645-x]

5. Chênevert J, Duvvuri U, Chiosea S, Dacic S, Cieply K, Kim J, Shiwarski D, Seethala RR. DOG1: a novel marker of salivary acinar and intercalated duct differentiation. Mod Pathol. 2012 Jul;25(7):919-29. [Medline: 22460810] [doi: 10.1038/modpathol.2012.57]

6. Khurram SA, Speight PM. Characterisation of DOG-1 Expression in Salivary Gland Tumours and Comparison with Myoepithelial Markers. Head Neck Pathol. 2019 Jun;13(2):140-148. [Medline: 29671211] [PMC free article: 6513803] [doi: 10.1007/s12105-018-0917-3]

7. Haller F, Bieg M, Will R, Körner C, Weichenhan D, Bott A, Ishaque N, Lutsik P, Moskalev EA, Mueller SK, Bähr M, Woerner A, Kaiser B, Scherl C, Haderlein M, Kleinheinz K, Fietkau R, Iro H, Eils R, Hartmann A, Plass C, Wiemann S, Agaimy A. Enhancer hijacking activates oncogenic transcription factor NR4A3 in acinic cell carcinomas of the salivary glands. Nat Commun. 2019 Jan 21;10(1):368. [Medline: 30664630] [PMC free article: 6341107] [doi: 10.1038/s41467-018-08069-x]

8. Haller F, Skálová A, Ihrler S, Märkl B, Bieg M, Moskalev EA, Erber R, Blank S, Winkelmann C, Hebele S, Baněčková M, Wiemann S, Müller S, Zenk J, Eils R, Iro H, Hartmann A, Agaimy A. Nuclear NR4A3 Immunostaining Is a Specific and Sensitive Novel Marker for Acinic Cell Carcinoma of the Salivary Glands. Am J Surg Pathol. 2019 Sep;43(9):1264-1272. [Medline: 31094928] [doi: 10.1097/PAS.0000000000001279]

9. Barasch N, Gong X, Kwei KA, Varma S, Biscocho J, Qu K, Xiao N, Lipsick JS, Pelham RJ, West RB, Pollack JR. Recurrent rearrangements of the Myb/SANT-like DNA-binding domain containing 3 gene (MSANTD3) in salivary gland acinic cell carcinoma. PLoS One. 2017 Feb 17;12(2):e0171265. [Medline: 28212443] [PMC free article: 5315303] [doi: 10.1371/journal.pone.0171265]

10. Andreasen S, Varma S, Barasch N, Thompson LDR, Miettinen M, Rooper L, Stelow EB, Agander TK, Seethala RR, Chiosea SI, Homøe P, Wessel I, Larsen SR, Erentaite D, Bishop JA, Ulhøi BP, Kiss K, Melchior LC, Pollack JR, West RB. The HTN3-MSANTD3 Fusion Gene Defines a Subset of Acinic Cell Carcinoma of the Salivary Gland. Am J Surg Pathol. 2019 Apr;43(4):489-496. [Medline: 30520817] [doi: 10.1097/PAS.00000000000001200]

11. Skaugen JM, Seethala RR, Chiosea SI, Landau MS. Evaluation of NR4A3 immunohistochemistry (IHC) and fluorescence in situ hybridization and comparison with DOG1 IHC for FNA diagnosis of acinic cell carcinoma. Cancer Cytopathol. 2021 Feb;129(2):104-113. [Medline: 32809265] [doi: 10.1002/cncy.22338] 
12. Nguyen L, Chopra S, Laskar DB, Rao J, Lieu D, Chung F, Kim ED, de Peralta-Venturina M, Bose S, Balzer B. NOR-1 distinguishes acinic cell carcinoma from its mimics on fine-needle aspiration biopsy specimens. Hum Pathol. 2020 Aug;102:1-6. [Medline: 32416209] [doi: 10.1016/j.humpath.2020.05.001]

13. Vargas AC, Maclean FM, Bonar F, Mahar A, Gill AJ. NR4A3 Immunohistochemistry Lacks Sensitivity for the Diagnosis of Extraskeletal Myxoid Chondrosarcoma. Am J Surg Pathol. 2019 Dec;43(12):1726-1728. [Medline: 31414988] [doi: 10.1097/PAS.0000000000001346]

14. Kas K, Voz ML, Röijer E, Aström AK, Meyen E, Stenman G, Van de Ven WJ. Promoter swapping between the genes for a novel zinc finger protein and beta-catenin in pleiomorphic adenomas with $t(3 ; 8)(\mathrm{p} 21 ; \mathrm{q} 12)$ translocations. Nat Genet. 1997 Feb;15(2):170-4. doi: 10.1038/ng0297-170. Erratum in: Nat Genet 1997 Apr;15(4):411. [Medline: 9020842] [doi: $10.1038 / \mathrm{ng} 0297-170]$

15. Weinreb I, Zhang L, Tirunagari LM, Sung YS, Chen CL, Perez-Ordonez B, Clarke BA, Skalova A, Chiosea SI, Seethala RR, Waggott D, Boutros PC, How C, Liu FF, Irish JC, Goldstein DP, Gilbert R, Ud Din N, Assaad A, Hornick JL, Thompson LD, Antonescu CR. Novel PRKD gene rearrangements and variant fusions in cribriform adenocarcinoma of salivary gland origin. Genes Chromosomes Cancer. 2014 Oct;53(10):845-56. [Medline: 24942367] [doi: $10.1002 /$ gcc.22195]

16. Antonescu CR, Katabi N, Zhang L, Sung YS, Seethala RR, Jordan RC, Perez-Ordoñez B, Have C, Asa SL, Leong IT, Bradley G, Klieb H, Weinreb I. EWSR1-ATF1 fusion is a novel and consistent finding in hyalinizing clear-cell carcinoma of salivary gland. Genes Chromosomes Cancer. 2011 Jul;50(7):559-70. [Medline: 21484932] [doi: 10.1002/gcc.20881]

17. Persson M, Andrén Y, Mark J, Horlings HM, Persson F, Stenman G. Recurrent fusion of MYB and NFIB transcription factor genes in carcinomas of the breast and head and neck. Proc Natl Acad Sci U S A. 2009 Nov 3;106(44):18740-4. [Medline: 19841262] [PMC free article: 2773970] [doi: 10.1073/pnas.0909114106]

18. Tonon G, Modi S, Wu L, Kubo A, Coxon AB, Komiya T, O’Neil K, Stover K, El-Naggar A, Griffin JD, Kirsch IR, Kaye FJ. $\mathrm{t}(11 ; 19)(\mathrm{q} 21 ; \mathrm{p} 13)$ translocation in mucoepidermoid carcinoma creates a novel fusion product that disrupts a Notch signaling pathway. Nat Genet. 2003 Feb;33(2):208-13. [Medline: 12539049] [doi: 10.1038/ng1083]

19. Skálová A, Vanecek T, Uro-Coste E, Bishop JA, Weinreb I, Thompson LDR, de Sanctis S, Schiavo-Lena M, Laco J, Badoual C, Santana Conceiçao T, Ptáková N, Baněčkova M, Miesbauerová M, Michal M. Molecular Profiling of Salivary Gland Intraductal Carcinoma Revealed a Subset of Tumors Harboring NCOA4-RET and Novel TRIM27RET Fusions: A Report of 17 cases. Am J Surg Pathol. 2018 Nov;42(11):1445-1455. [Medline: 30045065] [doi: 10.1097/PAS.0000000000001133]

20. Bishop JA, Weinreb I, Swanson D, Westra WH, Qureshi HS, Sciubba J, MacMillan C, Rooper LM, Dickson BC. Microsecretory Adenocarcinoma: A Novel Salivary Gland Tumor Characterized by a Recurrent MEF2C-SS18 Fusion. Am J Surg Pathol. 2019 Aug;43(8):1023-1032. [Medline: 31094920] [doi: 10.1097/PAS.0000000000001273]

21. Skálová A, Vanecek T, Sima R, Laco J, Weinreb I, Perez-Ordonez B, Starek I, Geierova M, Simpson RH, PassadorSantos F, Ryska A, Leivo I, Kinkor Z, Michal M. Mammary analogue secretory carcinoma of salivary glands, containing the ETV6-NTRK3 fusion gene: a hitherto undescribed salivary gland tumor entity. Am J Surg Pathol. 2010 May;34(5): 599-608. [Medline: 20410810] [doi: 10.1097/PAS.0b013e3181d9efcc]

22. Katabi N, Xu B, Jungbluth AA, Zhang L, Shao SY, Lane J, Ghossein R, Antonescu CR. PLAG1 immunohistochemistry is a sensitive marker for pleomorphic adenoma: a comparative study with PLAG1 genetic abnormalities. Histopathology. 2018 Jan;72(2):285-293. [Medline: 28796899] [PMC free article: 5730461] [doi: 10.1111/his.13341]

23. West RB, Kong C, Clarke N, Gilks T, Lipsick JS, Cao H, Kwok S, Montgomery KD, Varma S, Le QT. MYB expression and translocation in adenoid cystic carcinomas and other salivary gland tumors with clinicopathologic correlation. Am J Surg Pathol. 2011 Jan;35(1):92-9. [Medline: 21164292] [PMC free article: 3127258] [doi: 10.1097/PAS.0b013e3182002777]

24. Haller F, Moskalev EA, Kuck S, Bieg M, Winkelmann C, Müller SK, Ihrler S, Märkl B, Eils R, Wiemann S, Iro H, Hartmann A, Agaimy A. Nuclear NR4A2 (Nurr1) Immunostaining is a Novel Marker for Acinic Cell Carcinoma of the Salivary Glands Lacking the Classic NR4A3 (NOR-1) Upregulation. Am J Surg Pathol. 2020 Sep;44(9):1290-1292. [Medline: $\underline{32341238}$ ] [doi: 10.1097/PAS.0000000000001494]

\section{To cite this article:}

Owosho A, Tyler D, Adesina O, Odujoko O, Summersgill K.

NR4A3 (NOR-1) Immunostaining Shows Better Performance than DOG1 Immunostaining in Acinic Cell Carcinoma of Salivary Gland: a Preliminary Study

J Oral Maxillofac Res 2021;12(1):e4

URL: http://www.ejomr.org/JOMR/archives/2021/1/e4/v12n1e4.pdf

doi: $10.5037 /$ jomr.2021.12104 
Copyright (C) Owosho A, Tyler D, Adesina O, Odujoko O, Summersgill K. Published in the JOURNAL OF ORAL \& MAXILLOFACIAL RESEARCH (http://www.ejomr.org), 31 March 2021.

This is an open-access article, first published in the JOURNAL OF ORAL \& MAXILLOFACIAL RESEARCH, distributed under the terms of the Creative Commons Attribution-Noncommercial-No Derivative Works 3.0 Unported License, which permits unrestricted non-commercial use, distribution, and reproduction in any medium, provided the original work and is properly cited. The copyright, license information and link to the original publication on (http://www.ejomr.org) must be included. 